\title{
EXPLORING CULTURAL LANDSCAPES OF KAZAKHSTAN IN A SEMIOTIC WAY
}

\author{
${ }^{1}$ R.T. Khassenova , ${ }^{2}$ M.S. Sarkulova
}

\begin{abstract}
The article considers the project "Tugan Zher" ("Homeland") of the Kazakhstani national program "Course towards the future: modernization of Kazakhstan's identity" and the possibility to resort to the works and ideas of the well-known Italian philosopher and semiotician, recognized expert in Middle ages Umberto Eco while implementing the program, as in his numerous works the Italian scientist reflects much on the meaning of such notions like signification, reconstruction and memory. His philosophy of culture is the study of signs and languages and belief that understanding of the world requests understanding how we interpret it through the language and signs we use, constant mediation that stands in the way between us and the world. The poetics of openness, advocated much by $\mathrm{Eco}$, is especially actual under the current realities. The present research proves the semiotic concept of $U$. Eco to be effective in exploring cultural landscapes, which being regarded as signs, carriers of some valuable information, add much to the spiritual legacy of the nation.

1,2 L.N. Gumilyov Eurasian

National University,

Nur-Sultan, Kazakhstan

Corresponding Author:

R.T. Khassenova,

roza.tolengut.kz@mail.ru

Reference to this article:

Khassenova R.T.,

Sarkulova M.S. Exploring

Cultural Landscapes of

Kazakhstan in a Semiotic Way

// Adam alemi. - 2021.

- No. 4 (90). - P. 11-20.

Keywords: Kazakh, Culture, Landscape, Sign, Semiotics, Interpretation, Umberto Eco.
\end{abstract}

\section{Қазақстанның мәдени ландшафттарын семиотика тұрғысынан қарастыру}

\begin{abstract}
Аннотация. Ұсынылып отырған мақалада «Болашаққа бағдар: рухани жаңғыру» Қазақстандық ұлттық бағдарламасы аясында жүзеге асырылып жатқан «Туған жер» жобасы тілге тиек етіліп, жобаны іске асыру барысында итальян философы, семиотигі, Орта ғасыр мәдениетінің зерттеушісі Умберто Эконың еңбектеріне жүгіну мәселесі ұсынылады, себебі ол өз еңбектерінде тіл, мән, мағына, белгілер, реконструкция және жады мәселелерін көп қарастырады. Умберто Эко мәдениет философиясында тілдер мен белгілерді зерттеу және сол арқылы әлемді түсіну, адам мен әлем арасында тұрақты келісімге деген сенімнің болуы, оны өзіміз қолданып жүрген тіл мен белгілерді қалай пайдаланып, қалай түсіндіріп жүргенімізге байланысты деген болжам айтады. Зерттеушілер У.Эконың еңбектерінде көп мән берілетін ашықтық поэтикасы бүгінгі күнгі ізденістерде өте өзекті және қажет тәсіл деген пікір білдіреді. Жүргізілген зерттеу мәдени ландшафтты зерттеу барысындағы У.Эконың семиотикалық концепциясының зор тиімділігін көрсетіп, семиотиканы құнды ақпарат көзі ретінде қарастыру ұлттың мәдени мұрасына өз үлесін қосатынын дәлелдейді.
\end{abstract}

Түйін сөздер: Мәдениет, ландшафт, белгі, семиотика, интерпретация, Умберто Эко. 


\title{
Анализ культурных ландшафтов Казахстана сквозь призму семиотики
}

\begin{abstract}
Аннотация. В статье рассматриваются вопросы реализации проекта «Туған жер»казахстанской национальной программы «Взгляд в будущее: модернизация общественного сознания» и возможность обращения к трудам известного философа, семиотика и знатока Средневековья Умберто Эко, в ходе реализации данных проектов, так как в своих многочисленных трудах итальянский ученый много размышляет о таких понятиях как означивание, реконструкция и память. Философия культуры Эко предполагает изучение знаков и языков и вера в то, что для познания мира необходимо понять как мы интерпретируем его через язык и знаки, которые мы используем, постоянную медиацию между нами и миром. Поэтика открытости, много пропагандируемая Эко, особенно актуальна и необходима в современных условиях. Данное исследование подтверждает эффективность семиотической концепции У.Эко в исследовании культурных ландшафтов, которые при рассмотрении в качестве знаков, носителей ценной информации, вносят свой вклад в духовное наследие народа.
\end{abstract}

Ключевые слова: казахский, культура, ландшафт, знак, семиотика, интерпретация, У. Эко.

\section{Introduction}

One of the greatest projects of the Kazakhstani national program "Course towards the future: modernization of Kazakhstan's identity", launched in April 2017, the core idea of which is "love for one's land, for one's village, city, region, with love for a small homeland", is called "Tugan Zher" ("Homeland"). It proposes ways of preserving traditions and successfully adapting to the strong challenges of the future [1].

"Homeland", "umbilical cord blood", these notions are special for every Kazakh. A care to its culture and customs, as the basis of the cultural code, which makes every single nation unique, make the core of patriotism. This work should start at schools, studying and exploring the native land. One of the approaches to take in this regard, proposed in the present paper is a semiotic one, considering the world as signs.

Land and water names in the scientific language are called "toponymy", meaning from Greek a "place name". Thousands of names were given to rivers, lakes, mountains, hills, where Kazakhs have lived since ancient times. They were really skillful and ingenious in naming each of them. These names have been preserved for centuries. The phenomenon of these names is in the fact, that they make the spiritual legacy of the past, in some cases old, mystic notions. Often, original place names, politically forbidden in the past, are being restored and need thorough studies and explanations. Every such name is like a passport of the place. It is an indicator of the people, their culture and history. Therefore, the loss of the name means losing one's identity, while, on the contrary, restoring its meaning leads to spiritual regeneration, returning to one's roots. As Eco writes in his novel "L'isola del giorno prima", a human is the sum of his past records and everything in the living nature, animals and plants, even stones have their own memory. Memory is one of the abilities of soul, and despite the size, which should be small in stones, memory they possess [2, p. 214].

"To have a memory" means understanding the difference between the past and present.

The name of an object is a linguistic image, formed as a result of the combination of national consciousness and national taste, created in accordance with the peculiarities of the worldview of the nation. Language is the spirit of the nation. It reflects its spiritual wealth.

According to Eco, understanding the world implies understanding how it is interpreted through the signs and language used. All the cultural phenomena should be considered as communication signs and appropriate instruments should be found to clear out their communicative structure [3, p. 491].

\section{2 \\ АДАМ ӘЛЕМ \\ №4 (90) 2021, желтоқсан}




\section{Methodology}

As methodological basis we resort to Umberto Eco's semiotic method of interpretation of culture, to see its effectiveness in signification of cultural landscapes. As we read in his numerous works, semiotics has to do with everything, that can be accepted as a sign. And a sign is everything that can be accepted as a substitution of something else [4, p. 26].

According to Eco if today everything is turned into sign systems, it is because we can't imagine something without turning it into a sign. The role of culture is in giving meaning to the natural world, consisting of presence, turning the presence into meaning. Thus, to consider some message as a system of signified, connoting possible meaning, enables us to understand every "rest" of the meaning like a contribution of concrete people, living in concrete society, which make the presence speak, imparting it with meanings. It is very sad, that great forms are losing their original property to signify and we see them big and complex with very poor meanings and scarce information [5, p. 364].

Adhering to semiotics, one can find out why and how some notion takes a signification in the society at some historic point, how it is communicated and how it is transformed by the time. It is namely semiotics, which enable us to draw conclusions in a very thorough way and not just trusting our inner voice or intuition.

\section{Literature Review}

In his works, beginning from "Opera aperta", Eco advocates the active role of the interpreter, important under the current conditions of life, full of fake news. Such an approach is needed while engaging with any discourses and sign systems. The reader should know that every image and phrase is open to numerous senses, which he has to reveal, using proper codes [6, p.14].

Besides, one of the main ideas Eco elaborates in his writings ( $A$ theory of semiotics, The role of the reader, Semiotics and philosophy of language) is the Peircean idea of unlimited semiosis. According to Peirce, semiosis is "an action, or influence which involves an operation of the sign, its object, and its interpretant". As Eco writes, the sign is the origin of the semiosic processes, and there is "no opposition between the "nomadism" of semiosis and ... immobility of the sign. The semiosic process of interpretation is present at the very core of the concept of the sign" [7, p. 1].

Unlimited semiosis does not mean, that interpretation has no criteria. There are unacceptable interpretations. The interpreted text imposes some constraints upon interpreters. The limits of interpretation coincide with the rights of the text. One of the fundamental principles in Peirce's semiotics is "A sign is something by knowing which we know something more". In the course of unlimited semiosis we learn much about the representamen, which started the interpretative chain $[8, \mathrm{p}$. 37].

Eco suggests the universe of semiosis in the format of a labyrinth, which regulates such issues like metaphor, symbol and code. In their turn reading and deciphering metaphors need encyclopedic competence.

The significance of Eco's poetics is in its openness, the dialogic nature of semiosis, the capacity of the sign "to open up into something new". Eco's interpretant is "a collective, public, observable product laid down in the course of cultural processes". Eco supports Peirce's view on sign, negating the private sign model and advocating the social element in signs: It is not "my", but "our" experience that has to be thought of; and this "us" has indefinite possibilities [9].

For Eco a sign is "everything that, on the grounds of a previously established social convention..." (10, p. 16).

It deals on the semiotics of culture, when all the cultural phenomena are considered like texts. The components of culture are kept in the information, passed through signs. Culture is not some fixed form. It is created by human beings, as a 
result of their activity. We create culture and its signs, learn to read them and signs of other cultures.

Semiotics at present is widely represented as a discipline at educational establishments of Europe, USA and Canada; world congresses and conferences are held annually; specific journals have been founded. In Kazakhstan such studies are also gaining momentum. Thus, A.Kajgali is known with his research on Kazakh ornaments, H. Argynbayev, Zh. Abikenov and $\mathrm{S}$. Kudaibergenov consider semiotics of the cultural values, N. Aljanova analyses the semiotics of the Kazakh communicative culture.

The well-known Russian semiotician V. Ivanov underlined the big role semiotics play for a correct orientation in the history. He wrote that different sciences and approaches should supplement each other, facilitating the creation of a common picture of signs and texts, building the history of the human culture [11, p. 795].

Eco's interpretative semiotics is highly influential and has become a point of reference for the theory of signification. He is called one of the fathers of this science $[12$, p. 2].

Eco's theory of sign has been the subject of a number of studies that have addressed this issue from different standpoints: signification (M. Leone 2020), semiotics (J. Johansen 1993; M.Caesar 1999; U.Volli 2003; A.M.Lorusso 2005, 2015; A.Usmanova 2000; E. Brazgovskaya, 2019), philosophy (C. Farronato 2003). However, accurate studies have not yet given a systematic view on Eco's theory of the sign.

Considering messages on the basis of conventional codes is called "semiology" by Eco and as circumstances provide for clearing out the codes in the process of de codification, instead of changing the messages we can change the communication process, affecting circumstances, in which the message is received. It is crucial in the epoch, when mass media become the tool of power and to achieve the aim there is always a possibility to change the circumstances, if you can't change the message.

Not always it is easy to read the message, as the codes can be unfamiliar to us. Thus, it is necessary to restore the most appropriate code and check the correctness of your choice. The appropriateness of the code depends on the logic of the signified, which is the product of the codification process, called by the sense making mechanism. At the very moment of getting a message we get some fundamental codes [13, p. 467].

\section{Semiotics of the Name of the River "Soqyr"}

The research is conducted in Saryarqa region of Kazakhstan, once the heart of Altyn Orda (the Golden Horde), where thousands of toponyms date back to antiquity. The original name of the region was Arqa (transl. "back"). It was around the year 1000, when Deshty Qypshak tribes started unification processes and leaving the inhabited places moved to regions, better in political and strategic senses. Therefore, the native places, left behind, took the name "Arqa". In AltynOrda age it becomes Sary Arqa ("sary" transl. "yellow"), but it means not only color in this case. It means "vast, endless Arqa". In Kazakh culture "yellow" is used for intensification. "Saryayaz" (transl. yellow frost) means a severe frost. Thus, the name "Sary Arqa" is like a poetic name of the vast steppe. Besides, it signified its "rearward".

Nowadays Saryarqa is associated only with Central Kazakhstan and Qaragandy city, though it's not right. Originally Sary Arqa indicated the whole Uly Dala Great steppe up to the Edil river [14].

This city is brightly depicted in the Russian folklore: "Gde-gde? v Karagande". Karaganda is Russian for Qaragandy. It is the hometown of the well-known today in the world of sport boxer Genadi Golovkin, known as GGG. Besides, it is here where the first Kazakh cosmonaut T. Aubakirov was born. But this city is also known as one of the Kazakh Gulag camps, known as Karlag, where thousands of victims of political repressions were sent and died in

\section{\begin{tabular}{l|l}
14 & АДАМ ӘЛЕМІ \\
№4 (90) 2021, желтоқсан
\end{tabular}}


Stalin era. It is then, as one of the legends says, when the saying appeared, when people returning homes after many years in camps responded the question on where they had been so long: "Gde-gde? v Karagande".

The river Soqyr (transl. blind), with monuments of the Stone and Bronze Ages along it, runs across the city. Why is it called Soqyr (blind)? The research leads to the historic personality of Zhalantos batyr (kaz. batyr-hero), once known as Soqyr among the people, the nickname almost forgotten. The mausoleum, erected in 1996 for the 300 anniversary of the hero, is located to the south of Karaganda, along the road, leading to the "Saryarqa" airport. The hero is buried on the hill, called "Soqyrtobe" ("Blind Hill"). These names do not signify anything for the majority of the townspeople. Though, it is here, where the patriotic education should start. There is a Kazakh proverb: If there is no care of the heroes, there will be no heroes, caring for the land. (Erim degen el bolmasa, elim degen er qaydan bolady). Such an indifference to proper land and its past leads to the absence of patriotism. The grave of the hero was forgotten up to 1977, when hiding from Soviet authorities the descendants could put a stone sign on the grave. In thirty years of Independence is also done not so much. It is in plans to name a street in its name in Qaragandy, to put the place into the map of "Sacred places of Kazakhstan", make a film and organize an expedition to the heroic places.

The poems of M. Khaliolla, Zh. Qashkynov, A. Shaikhy, M. Baimukhanov depict well Zhalantos batyr's victorious battles for the liberty of the nation. One of the poems says:

Zhalantos batyr Qulyqtan,

Ardaqty bolgan ulyqtan.

Ol kisinin tusynda,

Zhamandyqty khalyq umytqan.

Translated:

Zhalantos batyr is son of Qulyq,

Was of the most respected folk.

In the times the hero lived,

The nation forgot what was bad.
From this poem we learn that he was a real person, the son of Qulyq and he did much for his nation. The real name of Soqyr batyr (blind hero), Zhalantos batyr (1698-1775), is in fact a well-known personality, one of the reliable companions of Bogenbay batyr (a legendary person) during the Dzungar invasion. Bogenbay Batyr is Zhalantos's uncle. Zhalantos batyr took part in the battles along the river Sarysu, near the lake Balkhash and Karaganda, around Shu, Ayagoz, Karkaraly, Bayanaul together with Kerney Jarylgap, Alteke Jidebay, Karashor Senkibay batyrs. He was close friends with Oljabay, Jasybay, Koshet batyrs. In Bayanaul, there is a place called "Zhalantos hill", mentioned in Dikhan Abilev's poem "Zhasybai batyr" and in the novel "Sultanmakhmut" [15].

In one of the greatest battles near Qaragandy, an arrow hit the hero in the eye. None of his companions dared to pull out the arrow. He did it himself, pulled it out and threw it into the river. From then on the river has been called Sokyr. That time Zhalantos batyr liberated the whole Qaragandy region from Dzhungars and chose as a place for his summer pasture along the river, also called Sokyr after him, one of the tributaries of the Nura river. Since then this place has been known for a long time as the "Soqyr Soran". Soran means high, lonely. It was the place, where Zhalantos batyr stood guard. Later, the present city Saran settled there. "Saran" is the Russian version of "Soran".

Zhalantos batyr passed his winters near the mountains Qyzyltas, Qarakozy and Maitas between the rivers Tokyrauyn and Jamshy on the shores of the lake Balqash. Qyzyltas is still called "Zhalantos" Qyzyl tasy" by the locals. The name of the place "Zhalantos" three reserves" has been preserved up today. After the battle, which he won, Zhalantos batyr brought back the only sister of the Qalmyq, who shot him in the eye, with two qula aygyrs (aygyr a horse and qula - the color of the horse; the head and body are shiny yellow or sandy yellow, the legs below the knees and the tail are black, with a thin black stripe 
extending from the top to the end of the tail. The body hair is shiny like gold; such a horse is called qulaker (qulager, kerkula). Near Qaraganda there is still a place, called Qulaigyr, in honor of those events.

The name Qulager is highly valued in Kazakh culture, reminding also on the tragic life of the outstanding poet and composer of the XIX century Aqan Seri and his Qulager. There is a film "Qulager" produced in 1972 by Kazakh film studio. The storyline is taken from life. There is also a well-known poem by I. Jansugurov with the same name. The film is based on the poem, depicting a well known among Kazakh people Sagynay bay's (kaz. "bay" a rich person) funeral, where lots of people gathered. Aqan Seri is also invited and though he does not want to go, because of the enemies, which for sure will be there, eventually the poet joins the event, persuaded by his country men. Traditionally in such cases a horse race is organized. Aqan Seri adds his Qulager to the race and gives the reins to a dumb boy. However, Kulager does not reach the finish line. His rivals decide to do everything not to let him win the race. Seeing that their horses are left behind, they not only harm Kulager, but beat him to death.

In the poem "Enseligim eki eli" (M. Otemissov') Qulager is shown as the pride of every Kazakh and one of our national symbols. In this poem Qulager is pictured along with other symbols, like the flag, hero and the musical instrument dulyga.

The example with the name Qulager, leading us in different directions, demonstrates how the process of unlimited semiosis works, the active role of the reader in it.

\section{Ulytau...What Secrets Does this Name Hide?}

To revive the history of the native land several expeditions have been organized to the historical settlements. One of them was organized to Ulytau (transl. "Uly" - great, "tau" - mountain). Kazakhs say: "Ult uyasy - Ulytau", transl. "the nest of the nation is Ulytau", "Ulytau - jer kindigi" (transl. earth button). Muslims never call a mountain "Uly" ("great"). Only the Creator can be great and only Allah is called "Uly" in Kazakh culture. Then why is it called "Ulytau"? It shows the recognition of the place in the history of the Great steppe. Ulytau is included into the list of the World heritage of UNESCO: "the archeological remains of the Ulytau landscape show full evidence of all the phases of the human history and of the human interaction with the natural environment: ancient mines, settlements, burials, petroglyphs... The mausoleum of the mythical first khan of the Kazakhs, Alasha khan, is located here; and so the only three preserved mausolea of the Golden Horde, the ones of Jochi-Khan..." [16].

There is a place called Khan Orda, where the inauguration of all the Kazakh khans took place beginning with Jochi Khan up to the last Kenesary khan. Inauguration is in Kazakh "ulyqtau". Prof. G. Essim expresses the idea, that Ulytau comes from the Kazakh "Ulyqta". It is very important for the whole nation as it signifies the state government system, taking its beginning from the Kazakh Khans, passing in those times a special ceremony of inauguration. It is a political term meaning recognition. The leaders of all the Kazakh tribes united in this place to show their trust to the newly elected Khan. Such a place was recognized sacred and was glorified in the songs and poems [17].

Interesting is also the view of the professor on the mausoleum of Alasha Khan, located in this region. Since Jochi khan times "Alash" became the national motto. Therefore Kazakh people believed Alash to be Jochi Khan's father. Historically there was a tradition to take fathers' names as motto of the tribes. Thus, Alash can be Shynghys Khan's pseudonym and it is Shynghys Khan buried near his son Jochi, who tragically died in his thirties. It happened in these places and remained in the people's memory. It is known that Ketbuga musician brought the knews to Shinghys Khan.

Ua, iyemiz, Shynghys Khan!

Dombyra ne dep jyrlaidy. 
Balan oldi - Joshy Khan!

Oh, my ruler Shinghys Khan!

What does the dombra tell us?

\section{Joshy Khan - Your Son died!}

There is no unanimous point of view among the scientists about the personality of the "mythical" mausoleum of Alasha Khan. Who is buried there?

There is another wide spread legend explaining the origins of the name "Alasha khan" (alasha - motley, versicolor). His father, Khan, being childless takes a second wife, who brings to life a motley child. Khan is told by his first wife to get rid of the son. So, the child was put into a chest and thrown into the sea. Luckily, he is found by a mendicant and becomes a strongman. In the end his father learns that his son is alive and sends his other sons to him. They elect him their Khan and call Alasha Khan [18].

A number of Kazakhstani scientists, among them B.llyassov support the idea that it is Shynghys Khan. The authors of the book "Shynghys Khan" E. Issakulov, Z. Orazbay also write that regarding his personality there are many mistakes, originating from the wrong translation of the work "Jamagat at tauarikh", when the word "mugul" was translated like "mongol". Besides, only on the territory of Kazakhstan, to the east of Saryarqa region, there is Shynghystau mountain.

In his essay "The power of a lie" Umberto Eco writes on the influence of the senses, truth and lie. Reminding on the false stories, known from his books, usually full of illusion, fantastic theories, which had different effect in the history, Eco writes that the real idea of his works was to warn his readers, that truth at any moment can turn into lie and the task of the society is to learn to confess one's failures.

The word "Alash" is one of the national codes. It was a slogan, as well as the name of the party, founded by A. Bokeikhanov, the name of the autonomy and the first government was Alash-Orda. Orda means "state".
A new discovery regarding the Temirlan monument on the Aqshoqy hill, has been made as a result of five years interdisciplinary work of a group of international archeologists, historians and scientists from Kazakhstan, Uzbekistan, Lithuania, Hungary and the USA. It has been proved, that on the hill there was a special fire construction erected by Temirlan, symbolizing one of the elements of the cult. The first writings on it as a "sign of the time" were in the XV century, left by Nizam-ad-Din Shami in "The book of Victories", later in 1706 on the map of Tartaria by the French cartographer Guillaume Delisle [19].

In his interview in Ulytau in 2014 the first President of the Republic of Kazakhstan $\mathrm{N}$. Nazarbayev underlined the role of this place in the history of the country saying, that it is the holy place, "umbilical cord blood" of the country. The highest pick of the mountain is called Auliye ata, transl. "Saint Father" and one of the streams is called Auliye bulaq. transl. "Saint stream" Ulytau is eyewitness of the history and we have to know it. As a tree without roots is weak, the same way the country without its history is not strong and can't stand hardships of the time.

Q.-Zh. Tokayev, the current President of the country in his travel to Ulytau in 2019 also spoke about the necessity to discover the hidden secrets of the place, to propagate the myths and legends, which will raise Kazakh culture to the next level. Ulytau has always been the historic and political center of the Great Steppe. According to the President Q.-Zh. Tokayev Ulytau is a golden cradle of the nation. It is the Golden Horde of Kazakh Khans. It is the place, where the Kazakh nation was united and raised the flag of unity.

Recognizing highly the significance of this place Herodotus wrote, that "the Saq tribes drew the footprints of their idols and these kinds of images can be encountered on the Terekti Auliye rocks and Ulytau Arganat rocks as well".

As we see, learning signs widens our horizons, they instruct us on the way 
of interpretation, leading us towards discoveries [20, p. 13].

\section{Conclusion}

All our research has been done around the semiotic ideas of the Italian philosopher Umberto Eco and their application to the cultural landscapes. An attempt has been done to explain the characteristics of the sign - vehicles analyzed in the study. Besides, we wanted to demonstrate that one of the decisive factors in the interpretation of meanings in the cultural landscapes is the intercourse between culture and semiotics.

The world around us is a text of signs. Each name represents some symbol. Every hill, mountain and river tells some story from the past, which should be preserved and passed to the future generations. It is a very complex phenomenon and as the study has proved the meaning and formation of toponyms can be determined from the worldview, customs and national mentality, the history and culture of the people living there.

A toponym generalizes information codified in it, if our attention is not on the syntax, but on the sign [21, p. 71-77].

To determine the meaning of a sign and decipher it, one should be able to understand and correctly interpret it. Mostly it deals on the mere de-coding of the message but often there is some uncoded element in. Therefore Eco underlines the role of interpretation and abductive hypothesis. The most important of a sign, as he writes, is that it does not just stand for something else, but it is also, something that can and should be interpreted. Thus, one of the key characteristics of a sign is its interpretability, showing what is signified by the sign. Signs signify some reality, determined by culture and according to one of the main principles of interpretation: "A sign is something knowing which we know something more" [22, pp. 2-93].

The meaning, assigned to a sign is determined by our perception and cultural orientation. "It is the human subject in culture that gives meaning to signs... $<>\ldots$ It is our culture and its framework of meaning which develops sign systems", as Bate writes [23, p. 95].

Very important is also to differentiate the meaning of the signs of culture and their significance. The first is evaluated by the individual subject, while the latter is culture related.

In the course of the study of cultural landscapes of the Saryarqa region we have found on the map of Qaraganda many streets, named after the personalities from the world history, like Marx, Lenin, Dzhalil, Molokov, Tereshkova, Potyomkin, Nakhimov. It shows the Soviet past of the city. In Kazakh culture settlements had not been named after a person before, only micro-toponyms [24, p. 45].

Semiotic methods of interpretation, search and research of symbols and codes increase our interest and participation, our possibilities in studying any subject. An example is given by Eco in his book "Inomedella Rosa", the intellectual mystery combining semiotics in medieval studies, biblical analysis, fiction and literary theory. Reading the novel one turns together with Franciscan friar William of Baskerville and Adso of Melk into Sherlock Holmes and doctor Watson. It's up to the readers to decide what is the 'rose' for in the title of the book. The novel begins with the phrase: "In the beginning there was a word" $[25$, p. 2].

In all his works Eco noted the significance of the language. Ours is the epoch of philology, he wrote, and it makes everyone be a philologist. It is the epoch of restoring memory, and it should be done with a tolerant attitude to the values of the past. Modern consumers of old forms should adjust to read messages, to look for proper keys. "Philological" abilities are at our disposal. A step towards the past will lead us into the future [26, p. 287].

Reading the texts of cultural landscapes is a complex process, where the "reader"becomes an interpreter of cultural codes, the vehicle of which is the landscape. It is crucial when the information is encoded by a different historical era. In 
the frames of this study we have limited only to the cultural landscapes of Saryarqa region. Such studies can be organized in the frames of the state project "Tugan zher" as many original place names have been changed and forgotten in different circumstances and expect their explanation and restoration and as this research shows the semiotic approach is to be adopted among the others.

\section{References}

1 www.akorda.kz/en/events/akorda_news/ press_conferences/course-towards-the-future modernization- of-kazakhstans-identity.

2 Eco U. L'isola del giorno prima. - M.: Bompiani, 1994. - P. 214.

3 Есо U. Отсутствующая структура. Введение в семиологию. - М.: Bompiani, 1968. - Р. 491.

4 Eco U. Trattato di semiotica generale.Milano: Bompiani, 1975. - P. 26.

5 Есо U. Отсутствующая структура. Введение в семиологию. - М.: Bompiani, 1968. - Р. 364-467.

6 Eco U. Opera aperta. - M.: Bompiani, 1967. - P. 14.

7 Eco U. Semiotics and the philosophy of language. - B.: Indiana university press, 1986. P. 1.

8 Eco U. The limits of interpretation. - B.: Indiana university press, 1990. - P. 37.

9 Campbell C. Exploring the textual woods. Umberto Eco's growing concept of text. - V.: Simon Fraser university, 2017. - P. 135.

10 Eco U. Theory of semiotics. - L.: Indiana University Press, 1976. - P. 16.

11 Иванов В. Избранные труды по семиотике и истории культуры. - Т. 1. - М.: YaRK, 1999. - 795 c.

12 Eco U. Theory of semiotics. - L.: Indiana University Press, 1976. - P. 2.

13 Есо U. Отсутствующая структура. Введение в семиологию. - М.: Bompiani, 1968. - Р. 467.

14 URL: https://e-history.kz/kz/news/ show/ 1146/2021-08-21-2019

15 URL: https://ortalyq.kz/zhala-t-s-so-yrbatyr-zh-ne-ma-an-ana/. 03.08.2017

16 Cultural landscape of Ulytau. URL: https://whc.unesco.org/en/tentativelists/1138/

17 Есім Ғ. Ұлытау Билік ордасы URL: https://abai.kz/post/38231 (2021-08-29)

18 Каскабасов С. Казахский фольклор в собрании Г.Н.Потанина. - А.: Наука, 1972. -
$67 \mathrm{c}$.

19 URL: https://express-k.kz/news/ issledovanie/pamyatnik_ustanovlennyy_ tamerlanom_v_ulytau_

20 Eco U. Il segno rivisitato. Per una storia della semiotica: teorie e metodi. P.: Quaderni del circolo semiologico siciliano, 1981. - P. 13.

21 Агеева Р. Топонимия как источник изучения истории заселения края. - М.: 1979. P. 71-77.

22 Eco U. Semiotics and the philosophy of language. - B.: Indiana university press, 1986. P. 2-93.

23 Bate Stuart C. Human Life is Cultural: Introducing Anthropology. - P.: Cluster Publications, 2002. - P. 95.

24 Мырзахметұлы М. Жаңа дүние және ономастика // Ономаст. хабаршы. - №1 (33), 2017. - Р. 45.

25 Eco U. Il nome della Rosa. - Milan: Bompiani, 1980. - P. 2.

26 Есо U. Отсутствующая структура. Введение в семиологию. - М.: Bompiani, 1968. - Р. 287.

\section{Transliteration}

1 URL: www.akorda.kz/en/events/akorda_ news/press_conferences/course-towards-thefuture modernization- of-kazakhstans-identity. Date Accessed: 2020-07-02

2 Eco U. L'isola del giorno prima [The island of the day before]. - M.: Bompiani, 1994. - P. 214. (In Ital)

3 Eco U. Otsutstvuyushaya struktura. Vvedeniye $\mathrm{v}$ semiologiyu [Absent structure. Introduction to semiology]. - M.: Bompiani, 1968. - P. 491. (In Russ)

4 Eco U. Trattato di semiotica generale [The treatise of the general semiotics]. - M.: Bompiani, 1975. - P. 26. (In Ital)

5 Eco U. Otsutstvuyushaya struktura. Vvedeniye $\mathrm{v}$ semiologiyu [Absent structure.Introduction to semiology]. - M.: Bompiani, 1968. - P. 364-467. (In Russ)

6 Eco U. Opera aperta [Open work]. - M.: Bompiani, 1967. - P. 14. (In Ital)

7 Eco U. Semiotics and the philosophy of language. - B.: Indiana university press, 1986. P. 1. (in Eng)

8 Eco U. The limits of interpretation. - B.: Indiana university press, 1990. - P. 37. (in Eng)

9 Campbell C. Exploring the textual woods: Umberto Eco's growing concept of text. - Canada, 2017. - P. 135. (in Eng)

10 Eco U. Theory of semiotics. - London: Indiana University Press, 1976. - P. 16. (in Eng)

11 Ivanov V. Izbranniye Trudy posemiotike I is- 
toriicultury [Selected works on semiotics and culture]. - Moskva: YaRK, 1999. T.1. - S. 795. (In Russ.)

12 Eco U. Theory of semiotics. - London: Indiana University Press, 1976. - P. 2. (in Eng)

13 Eco U. Otsutstvuyushaya struktura. Vvedeniye $v$ semiologiyu [Absent structure. Introduction to semiology]. - M.: Bompiani, 1968. - P. 467. (In Russ)

14 URL: https://e-history.kz/kz/news/ show/1146/2021-08-21-2019 (In Kaz)

15 URL: https://ortalyq.kz/zhala-t-s-so-yrbatyr-zh-ne-ma-an-ana/. 03.08.2017 (in Kaz)

16 Cultural landscape of Ulytau. URL: https://whc.unesco.org/en/tentativelists/1138/

17 Essim G. Ulytau - Bilik ordasy [Ulytau the horde of power] // 2021-08-2 URL: https:// abai.kz/post/38231 (In Kaz)

18 Kaskabassov S. Kazakhskiy folklor vsobranii G.N. Potanina [Kazakh folklore in collections of G. N. Potanin]. - A.: Nauka, 1972. - P. 67-68. (in Kaz)

19 Pamyatniku stanovlenni Tamerlanom nakonets to issledovan uchenymi [The monument put by Temirlan is studied by scientists.]// 27.11.2020. URL: https://express-k.kz/ news/ issledovanie/ pamyatnik_ustanovlennyy_tamerlanom_v_ulytau_nakonets_to_issledovan_ uchenymi-170341 (In Russ)
20 Eco U. II segno rivisitato. Per unastoriadellasemiotica: teorie e metodi [The sign revisited. For a story of semiotics: theories and methods]. - P.: Quaderni del circolosemiologico siciliano, 1981. - P. 13. (In Ital)

21 Ageeva R. Toponimiya kak istochnik izucheniya istorii zaseleniya kraya [Toponymy as a sourse for studies in history]. - M., 1979. P. 71-77. (In Russ)

22 Eco U. Semiotics and the philosophy of language. - B.: Indiana university press, 1986. P. 2-93. (in Eng)

23 Bate Stuart C. Human Life is Cultural: Introducing Anthropology. - P.: Cluster Publications, 2002. - P. 9. (in Eng)

24 Myrzakhmetuly M. Jana duniye jane onamastica maselesi [The new world and the issue of onomastics] // Onomasticalyq khabarshy. 2017. - №1 (33). - P. 45. (In Kaz)

25 Eco U. Il nomedella Rosa [The name of Rose]. - Milan: Bompiani, 1980. - P. 2. (In Ital)

26 Eco U. Otsutstvuyushaya struktura. Vvedeniye $v$ semiologiyu [Absent structure. Introduction to semiology]. - M.: Bompiani, 1968. - S. 287-467. (in Russ.)

\section{INFORMATION ABOUT AUTHORS}

Roza Khassenova

Manifa Sarkulova

Роза Тукеновна Хасенова

Манифа Стаболовна Саркулова

Роза Тукеновна Хасенова

Манифа Стаболовна Саркулова
PhD student, L.N.Gumilyov Eurasian National University, Nur-Sultan, Kazakhstan

Candidate of Philosophical Sciences, Assistant Professor, L.N.Gumilyov Eurasian National University, Nur-Sultan, Kazakhstan

$\mathrm{PhD}$ докторант, Л.Н.Гумилев атындағы Еуразия Ұлттық университеті, Нұр-Сұлтан, Қазақстан

философия ғылымдарының кандидаты, доцент, Л.Н.Гумилев атындағы Еуразия Ұлттық университеті, Нұр-Сұлтан, Қазақстан

$\mathrm{PhD}$ докторант, Евразийский национальный университет им. Л.Н.Гумилева, Нур-Султан, Казахстан

кандидат философских наук, доцент, Евразийский национальный университет им. Л.Н.Гумилева, НурСултан, Казахстан 